\title{
A Study of the Present Situation and Characteristics of College Students' Ideology and Morality
}

\author{
Zhongfang Chen
}

\author{
Guangdong University of Science \& Technology, Dongguan, China
}

Keywords: private colleges and universities; college students; ideology and morality; education

\begin{abstract}
With the deepening of the understanding of the status of private higher education in China's socialist education, many scholars have made many and beneficial explorations and studies on the theory and practice of ideological and political education in private colleges and universities and have obtained a lot of valuable research results, And put forward some constructive comments and suggestions on how to improve and strengthen the ideological and political education of private colleges and universities. However, the ideological and political education of private colleges and universities in China still faces many difficulties and challenges, such as: the state should be how to private ideological and political education of the theoretical guidance and legal norms? How to Improve the Understanding of the Significance of Ideological and Political Education by the Private University Students? The following article will analyze the status and characteristics of the ideological and moral education of private college students, and offer some constructive suggestions for the improvement of the ideological and moral level of the private college students.
\end{abstract}

\section{The Status Quo of Contemporary College Students' Morality}

\section{The ideological mainstream of contemporary college students}

The ideological mainstream of contemporary college students is: active, healthy and progressive. In view of the current socialist market economy in China under the conditions of the need for "Lei Feng spirit", the vast majority of students surveyed that is needed. Survey shows that the vast majority of students in today's increasingly competitive market economy conditions, to help others, after their ancestors Lei Feng spirit is still agreed and support, shows the young generation of students of our fine tradition of moral recognition.

The survey of 1227 students on the need for "Lei Feng spirit" attitude

\begin{tabular}{|l|l|l|l|l|l|l|}
\hline Attitude & Agree all & $\begin{array}{l}\text { Agree } \\
\text { basically }\end{array}$ & $\begin{array}{l}\text { difficult to } \\
\text { judge }\end{array}$ & disagree & $\begin{array}{l}\text { Have not } \\
\text { think }\end{array}$ & $\begin{array}{l}\text { Do not } \\
\text { know }\end{array}$ \\
\hline $\begin{array}{l}\text { number of } \\
\text { students }\end{array}$ & 675 & 360 & 43 & 107 & 35 & 7 \\
\hline proportion & $55 \%$ & $29.3 \%$ & $3.5 \%$ & $8.8 \%$ & $2.8 \%$ & $0.6 \%$ \\
\hline
\end{tabular}

\section{The current problems of ideological and moral problems of college students}

Positive and progressive ideological and moral mainstream of contemporary college students we fully affirmed, but not optimistic. In the survey, also found that the ideological and moral existence of a major hidden dangers, specifically in:

1) life values tend to diversification, the interests of.

Since the establishment of the socialist market economic system, a variety of trends together with the influx of college students. Believe in collectivism or individualism? Is focus on dedication or pay attention to obtain? Is the benefit or self-interest? Is the effort to learn or the pursuit of money, pleasure, excitement, comfort, leisure? All of these aspects of the value orientation, are presented in front of college students, for their selection and identification. But some students choose the value of life there is a wrong tendency.

2) ideological and moral understanding of the existence of bias.

According to the survey, in many colleges and universities $1 / 2$ of the people that the current social and moral life is more than the false and ugly truth and good and beautiful, and that the good 
and the beautiful more than false and ugly people less than 1 / There are 2/5 people are swinging people "There are a lot of things that people can not tell is good or bad."

3) ethics practice ability is poor.

College Students' Moral Cognition and Moral Behavior. The performance of moral values is not strong enough, poor quality of spiritual civilization. In the daily life, the bus has young and old on the bus, and many people pretend to sleep, filled with not seen; spitting in public places, throwing melon skin shell; in the campus to see the teacher not say hello, as did not see ; In the classroom there are vulgar desk culture and other undesirable phenomena everywhere.

4) ideals and beliefs awareness is not strong.

Some college students think that the final way out of education is not big, there is no future after graduation, so there to avoid learning the status quo. Such as: they have no interest in learning, loss of confidence in life, and some to meet teachers and examinations for the purpose of copying copy other people's work, test fraud, the good time wasted in dress, puppy love, network, fashion and other abandoned above Study.

\section{Analysis of the Current Situation of Contemporary College Students' Morality}

Marxist philosophy that: between things have a causal relationship. On the causes of the present situation of the ideological and moral of contemporary college students, we can from the following aspects:

Economic impact on college students thought and the market economy to the ideological and moral education difficult.

Reform and opening up the door wide open, various influx of ideas, so that students in which the cultural environment has changed, some students blindly Chongyang. Income and other factors so that some graduates will be foreign employment as a hot target, the motherland in the minds of some college students gradually played down. As far as college students are concerned, their social interface and acceptance of new things are much faster than teachers working in schools. And teachers often can not grasp the change and development of the social environment in advance, when the students who have reflected some ideological problems, the teacher was passive to education, which brought great difficulties to moral education, the teacher's preaching seemed weak Weak, targeted is not strong, let alone "timely" or even "ahead", resulting in ideological and moral education in college students lagging behind the situation.

Students of their own physiological and psychological and social development is uneven.

Psychological and physiological diseases are the result of the interaction between human beings and society and the natural environment. The influence of the external environment on the mental health of college students only provides a possibility, and this possibility should be transformed into reality, and ultimately through the main work, through the subject and the object of interaction and eventually completed. According to cognitive theory, external stimuli do not necessarily simply cause a reaction, there is a cognitive process between stimulation and response, that is, the evaluation of the subject. It is precisely because of the different cognition of the subject to the object that leads to different responses of quality, quantity and degree, and the cognitive structure of this subject is the result of the deposition of the subject in all these life experiences, including social and cultural factors.

\section{Social education, fatigue and family education out of control.}

As China is in the initial stage of the development of market economy and the transition period of the old and new systems, the market operation and the order of laws and regulations are not perfect, the harmonious, fair and just environment has not been fully formed. At the same time, family education on the one hand most of the students live on campus, away from their parents, family education and school education out of line.

\section{The Characteristics of College Students in Private Colleges and Universities}

Because of the public and private in the ideological and behavioral behavior in colleges and 
universities are biased, private schools after college students there is a large ideological pressure, because of lack of confidence will affect the study and life; the second is the dominant relationship between the school and students The balance between the traditional educator and the educated has changed, the relationship between the student and the school has become the relationship between the consumer and the consumer, the student is in the position of the consumer customer, the psychological change of the student forces the management way to change , The school is both managers and service providers; three private college students self-esteem strong, the lack of good study habits, hoping to get parents, teachers support, but refused to admit their own deficiencies, unwilling to accept criticism.

\section{The Particularity of Ideological and Political Education in Private Colleges and Universities}

Private education is to cultivate applied and compound talents as the goal of higher education, is different from the subject type, research type of general higher education. Therefore, to do a good job in ideological and political education of private colleges and universities should first figure out the characteristics of private education. To sum up the following are the main points:

\section{Private University's own particularity}

In recent years, the rapid development of China's private colleges and universities, mainly for the rapid development of the scale and the new or renovated private institutions more, but the private institutions is a social power school, all funding comes from their own, which led to China's private The backward development of colleges and universities, the existence of inadequate investment, poor school conditions or students are low volume of the problem. However, the construction and running of a modern privately-run institutions not only need land, school infrastructure, but also a high-quality teachers and a modern, high-level libraries and high-quality vocational skills training centers and other software facilities as Protection. As a self-supporting private institutions, it is difficult for the hardware and software needed for the construction of large, continuous, regular input to provide strong protection. Some school leaders realized the importance of ideological and political education, but when it conflicts with the economic interests of the school, especially the enrollment stage, in order to allow students to enroll, you can easily cancel the ideological or other educational activities. However, standing in the school point of view, the source is the source of private colleges and universities, no students, there is no school, no money, there is no faculty. Natural sense of crisis prompted private universities had to put students in the first place, enlargement of students to recruit students to society is not good impression is inevitable.

\section{The Complexity of Student Resources in Non - government Colleges and Universities}

Private colleges and universities compared to ordinary colleges and universities, the students in the structure is more complex: both general high school students, but also from secondary vocational education graduates, as well as adult students from the community, the level of students varies. Compared with ordinary college students, the students of private colleges and universities may also have the following adverse tendencies, mainly as follows: ideals and beliefs, some students have varying degrees of ideals and beliefs ambiguity, value orientation distortion and other issues. Psychological quality, private students have varying degrees of self-esteem, loneliness, anxiety, confusion and other psychological problems, self-adjustment capacity is weak. Learning attitude, the enthusiasm of learning is not high, lack of self-learning awareness and ability, very few students even "dawdle", the results worrying.

\section{The Countermeasures for the Management of Ideological and Political Education of the Non - governmental Institutions of Higher Learning}

To give full play to students in the ideological and political education in the main role.

In the ideological and political education of students to give full play to the subjectivity of students is the pursuit of ideological and political education the best results of the inevitable requirement. The purpose is to cultivate students 'ability of self-selection, self-education and 
self-evaluation through the guidance of ideological and political educators, that is to cultivate students' subjective consciousness and subjective ability. Change passive acceptance for students to learn, the effect will be good. This can be the first pilot in the student cadres.

\section{To build a stable, high-quality student ideological and political education team.}

Ideological and political work team is an important force in quality education, is to coordinate the school, society and family and other educational forces of the hub, requires ideological and political workers have a firm political stance, good sense of service, a responsible mind, Political workers.

\section{Reference}

[1] Analysis of the characteristics of private college students and management strategies, Cheng Ru Ping, Hubei Administration School, 2011

[2] A New Approach to the Management of Students' Characteristics in Private Colleges and Universities, Li Meisheng, Journal of Nanchang College of Education, 2013

[3] The new era of private college students ideological and political education difficult and countermeasure research, Yang Haitao, school party building and thinking education, 2012 